\title{
ENFERMEDADES EMERGENTES
}

\section{Influenza aviar: ¿debemos preocuparnos?}

Durante el año pasado, el público en general, y particularmente quienes laboramos en las áreas de la salud hemos estado pendientes del riesgo que representan las enfermedades infecciosas emergentes con la diseminación en varios países del mundo del síndrome respiratorio agudo severo (SARS), las amenazas de bioterrorismo, la proliferación del virus del oeste del Nilo y el descubrimiento en los Estados Unidos de América del virus de la viruela del mono. Paralelamente, la amenaza de una pandemia de influenza se hizo presente en 2003 cuando cepas altamente patógenas del virus de la influenza aviar, incluyendo los subtipos H5N1 y H7N7, cruzaron la barrera entre aves y humanos y causaron la muerte de varias personas. ${ }^{1}$

Desde mediados de diciembre de 2003, ocho países asiáticos (Camboya, China, Indonesia, Corea del Sur, Japón, Laos, Tailandia y Vietnam), reportaron influenza aviar en pollos y otras aves causada por el virus serotipo A (H5N1). Para el 25 de marzo de 2004, la Organización Mundial de la Salud (OMS) reportaba en Tailandia y Vietnam 34 casos humanos confirmados en el laboratorio, de los cuales 23 (67.6\%) habían fallecido por este virus. ${ }^{2}$

Características del virus de la influenza. Existen en la naturaleza tres tipos de virus de influenza: A, B y C. El primero se divide en subtipos de acuerdo con dos proteínas que se encuentran en la superficie del virus. Estas proteínas se denominan hemaglutinina (HA) y neuraminidasa (NA). Existen 15 subtipos diferentes de HA y nueve subtipos diferentes de NA. Las aves son los hospederos naturales de todos los subtipos de los virus de la influenza A. Hasta hoy, todos los brotes de formas altamente patogénicas han sido causados por los subtipos $\mathrm{H} 5$ y H7. Los virus de la influenza $B$ y algunos subtipos de la A (H1N1, H1N2 y H3N2) circulan normalmente en el humano causando epidemias anuales, particularmente durante el invierno. Los virus del tipo $C$ son menos patógenos y no causan epidemias. Además de las aves, los virus de la influenza tipo A pueden infectar a otros animales como puercos, caballos, focas y ballenas. Las aves migratorias, particularmente los patos, son las encargadas de dispersar los virus que se encuentran en sus heces, saliva y secreciones nasales y a los cuales son muy resistentes, a diferencia de las aves de corral, que son particularmente susceptibles a las epidemias con una mortalidad elevada. La cuarentena de granjas infectadas y la destrucción de animales potencialmente expuestos al virus son medidas de control que ayudan a prevenir la dispersión del virus y un eventual establecimiento del mis- mo en la población aviar. Además de ser altamente contagiosa, la influenza aviar se transmite fácilmente entre las granjas mediante medios mecánicos como equipos contaminados, vehículos, jaulas, y cualquier instrumento infectado con heces de las aves.

Los virus de la influenza A, incluyendo los que producen epidemias en los humanos, se encuentran bien adaptados para eludir las defensas inmunológicas del huésped al que infectan. Carecen de sistemas genéticos de reparación de su material genético durante la replicación en el humano, por lo que la cepa existente es remplazada con una variante antigénica nueva. Estos pequeños pero permanentes cambios antigénicos requieren de una vigilancia constante de la situación mundial de la influenza, con ajustes anuales de la composición de las vacunas contra la influenza. Estas actividades de vigilancia las lleva a cabo la OMS desde 1947.

Otra característica de estos virus, con implicaciones en la salud pública, es la capacidad que tienen los que provienen de diferentes especies de "rearreglar" su material genético, lo que da como resultado un subtipo diferente al de los dos virus originales. Debido a que las poblaciones susceptibles carecen de inmunidad contra este nuevo subtipo y no existen vacunas producidas contra él, estos cambios genéticos 
han generado pandemias altamente letales. Para que esto suceda, el nuevo serotipo debe contener genes de virus de influenza humanos para que se transmita fácilmente entre la población durante un tiempo determinado. $^{3}$

Influenza aviar H5N1 en humanos. El virus de influenza A (H5N1) implicado en el brote 2003-2004, ha sido parcialmente secuenciado. Todos los genes son de origen aviar y no han adquirido genes humanos. Se han demostrado pequeñas diferencias entre los virus que circulan en Vietnam y Corea del Sur, y el análisis de su secuencia demuestra resistencia a dos de los antivirales más comúnmente empleados: amantadina y rimantadina. Los otros dos antivirales, oseltamavir y zanamavir siguen siendo efectivos contra la cepa H5N1. El cuadro clínico de los casos incluye fiebre, dolor de garganta, tos $\mathrm{y}$, en algunos de los casos mortales, enfermedad respiratoria grave. Los más afectados han sido adultos y niños previamente sanos, y algunos pacientes con enfermedades crónicas. Medidas de protección, prevención y control. Una prioridad inmediata es detener la propagación de la epidemia en las poblaciones de aves de corral, estrategia que reduce las posibilidades de exposición humana al virus, para lo cual la OMS colabora con la Organización de las Naciones Unidas para la Agricultura y la Alimentación, y la Organización Mundial para la Salud Animal para proteger la salud pública internacio- nal. Desde diciembre de 2003 han muerto y se han sacrificado 100 millones de aves de corral para contener la epidemia con un impacto económico muy elevado. La vacunación de las personas con alto riesgo de exposición a las aves infectadas, usando las vacunas más eficaces contra las cepas circulantes de la influenza humana, permite reducir la probabilidad de coinfección del ser humano con cepas aviares.

La OMS ha iniciado acciones que incluyen apoyo a las autoridades nacionales en la investigación de brotes en Asia, producción de pruebas diagnósticas para la detección rápida de la infección H5N1 en seres humanos, producción de vacunas para la prevención y antígenos, y reactivos de laboratorio para diagnóstico en los centros nacionales de influenza. Esta información se encuentra disponible en la siguiente dirección: http://www.who.int/ csr/disease/avian_influenza/en/. ¿Debemos preocuparnos? Todos los virus de la influenza tienen la capacidad de cambiar genéticamente y adquirir la capacidad de transmitirse de persona a persona. Debido a que la emergencia de un nuevo subtipo con estas características implicaría que la población humana no tendría protección inmunológica contra él, estaríamos en riesgo de una pandemia. Expertos de la OMS aseguran que no se podría evitar la diseminación del virus a escala mundial pero se podría retardar. Se estima que al virus le tomaría entre cuatro y ocho meses viajar alrededor del mundo y la vacunación sería la principal defensa de la población. Sin embargo, la producción de una vacuna también tardaría varios meses en desarrollarse y producir grandes cantidades para evitar el desabasto, particularmente en los países en desarrollo en donde existe poca capacidad para la producción de vacunas. De los 190 países miembros de la OMS, únicamente 36 naciones cuentan con un programa de contingencia en caso de una pandemia.

Si bien en México, en este momento no hay ningún riesgo de contraer la enfermedad, ya que no se importan aves de ninguno de los países afectados, la Secretaría de Salud ha incrementado la sensibilidad del Sistema Nacional de Vigilancia Epidemiológica y continuará atenta a la información que se genere respecto a esta enfermedad, para que en caso necesario se alerte a la población sobre las medidas a tomar.

M en C Gabriela Echániz-Aviles. Centro de Investigación sobre Enfermedades Infecciosas, Instituto Nacional de Salud Pública. Cuernavaca, M orelos, M éxico.

\section{Referencias}

1.W ebby RJ,W ebster RG. Are we ready for pandemic influenza? Science 2003;302: 1519-1522.

2. Centers for D isease Control and Prevention. Cases of influenza A (H5N 1) - Thailand, 2004. MMW R Morb Mortal W ky Rep 2004;53: 100-103.

3. 2003-04 avian influenza outbreak. Disponible en: http://www.cdc.gov/flu/avian/outbreak.htm. Consultado en: 2004 febrero 4. 